\title{
Environmentally Friendly and Sustainable Production of Particle Board Using Maize Cobs
}

\author{
Ishimwe Cédrick ${ }^{1}$, Tuyisenge Nkusi Ange ${ }^{1}$, Nduwumwami Ivan ${ }^{1}$, Uwiduhaye Fabrice ${ }^{1, *}$, \\ G. Senthil Kumaran ${ }^{2}$ \\ ${ }^{1}$ Department of Civil, Environmental and Geomatic Engineering, College of Science and Technology, \\ University of Rwanda, Kigali, Rwanda \\ ${ }^{2}$ Department of Civil Engineering and Construction, The Copperbelt University, Kitwe, Zambia
}

Received March 1, 2021; Revised July 19, 2021; Accepted August 22, 2021

\section{Cite This Paper in the following Citation Styles}

(a): [1] Ishimwe Cédrick, Tuyisenge Nkusi Ange, Nduwumwami Ivan, Uwiduhaye Fabrice, G. Senthil Kumaran, "Environmentally Friendly and Sustainable Production of Particle Board Using Maize Cobs," Civil Engineering and Architecture, Vol. 9, No. 7, pp. 2278 - 2285, 2021. DOI: 10.13189/cea.2021.090715.

(b): Ishimwe Cédrick, Tuyisenge Nkusi Ange, Nduwumwami Ivan, Uwiduhaye Fabrice, G. Senthil Kumaran (2021). Environmentally Friendly and Sustainable Production of Particle Board Using Maize Cobs. Civil Engineering and Architecture, 9(7), 2278 - 2285. DOI: 10.13189/cea.2021.090715.

Copyright $\mathrm{C} 2021$ by authors, all rights reserved. Authors agree that this article remains permanently open access under the terms of the Creative Commons Attribution License 4.0 International License

\begin{abstract}
This research project was carried out to propose a new material made out of maize cobs for particle board manufacture. The purpose was to examine general limits within which a satisfactory board can be made with this agricultural residue. Mostly, maize cobs are considered as agriculture wastes. These natural and organic waste materials are sometimes being kept for a long time so that they can decompose for making fertilizers and others are burnt which is harmful to the environment and atmosphere as a whole. This study focuses on using maize cobs in production of a three-layer particle board for furniture where it was started by collecting maize cobs from local farmers in Gicumbi District and testing their physical and chemical properties using eye vision. After, cobs have been grinded in small particles by using flour mill machine and then sieved to retain particle of desirable dimensions. Since this board is composed of three layers, the particles are of two types. Small particles are 1 to $3 \mathrm{~mm}$ for both outer layers (face layers) and 4 to $6 \mathrm{~mm}$ for middle layer (core layer). Particles were then washed to remove dust, cooked for protecting particles from decaying after board production and sun dried at an average temperature of $27^{\circ} \mathrm{C}$ within 72 daylight hours for extracting moisture. Later, the prepared particles were mixed with sisal fibres and bonded together by glue and then formed into boards of different sizes with an average mechanical compression of 3.8 $\mathrm{N} / \mathrm{mm}^{2}$. Afterwards, the formed board was removed from
\end{abstract}

the formwork and exposed to the sun within 5 days for drying and hardening. After that, one of the hardened boards was covered by veneer cover for enhancing the external appearance and increasing its resistance to moisture. Lastly, the covered boards were tested for checking their efficiency. The results were compared with the data available from the present standard. All samples satisfied the standard requirements except for water absorption test. It was generally observed from the results that the maize cob is a good material for particle board manufacture and its properties were consistently dependent on the resin concentration levels and density. The developed product will be an environmentally friendly and sustainable product. This product will reduce the importation of particle boards from other countries and will encourage the SMEs to create the jobs, which will fulfill the Rwanda's vision.

Keywords Maize Cob, Particle Board, Sisal Fibers, Sustainable, Environmental Friendly

\section{Introduction}

The basic materials used in civil engineering applications are wood, cement and concrete, bitumen and 
bituminous materials, structural clay and concrete units, and structural steels and many more [1]. Among these materials, wood can be used to produce boards which are having different types of applications including plywood [2].

While producing different materials from wood like furniture, the saw dust that remains as chips are used to manufacture particle boards. Here, particle boards are a relatively new type of engineered wood or other particle product that are made from gluing together small chips like saw-dust, rice husks, wheat straws and so on [3].

These particle boards are having different applications such as in flooring, partitioning or wall paneling, in false ceiling, in core materials for doors, in commercial industry and in furniture industry like being used to make furniture to be used in offices, kitchen, bathrooms, storage units, bedrooms, wardrobes table tops, counter tops, computer tables, books shelves, etc. [4]. In Rwanda, particle boards that are used to manufacture furniture are imported, and are expensive and sometimes rare.

In Rwanda, there is only one industry producing particle board from agriculture wastes (wheat straws) but this paper has shown that maize cobs can be another alternative that can be used to manufacture these particle boards for different uses such as making furniture. The study of ministry of agriculture and animal resources in Rwanda has shown that in 2016 more than 374,000 tons of maize were produced, showing that Maize is one of the most crops cultivated in Rwanda [5]. a large amount of the maize harvests in Rwanda is produced into maize flour by different industries, others are consumed by people when they are still fresh, but after all, the maize cobs that are obtained after production and consumption are taken as wastes that need to be damped or disposed, and sometimes used as cooking materials that produces smokes which pollute the atmosphere.

This paper aims at using these maize cobs that are most of the times considered as wastes to produce a three-layer Maize cob particle board (MCPB) reinforced by sisal fibers for making furniture that will come as a solution for the above mentioned problem of expensive particle board imported in Rwanda to be used in making different materials as other particle boards like manufacturing furniture as well as making useful these maize cobs which are useless and burnt polluting the atmosphere. This particle board was produced starting by collecting maize cobs from northern province of Rwanda (Gicumbi district) and the best were selected from the decayed ones by use of eye vision, then the good ones selected were cooked to protect them from decaying; fourthly, they were sun dried at average temperature of $27^{\circ} \mathrm{C}$ daylight hours to remove moisture. After sun drying, maize cobs were grinded using flour mill machine to obtain particles of different sizes, then they were sieved and those obtained from $3 \mathrm{~mm}$ sieve have been used in two outer layers of the board, and those obtained from $6 \mathrm{~mm}$ sieve have been used in middle or intermediate layer. Later, the prepared particles were mixed with sisal fibres as reinforcements and bonded together by glue and then formed into boards of different sizes with an average mechanical compression of 3.8 $\mathrm{N} / \mathrm{mm}^{2}$ by the use of bench vices. The board obtained was covered by veneer to give better appearance as well as enhancing the moisture protection.

This final board was then tested to check its effectiveness and tests like water absorption, moisture content, screw penetration and flexural strength test were carried out. The results obtained from the tests were compared with the data from the Indian standard. It is shown that MCPB is an environmentally friendly, cost effective and sustainable better material to be used in manufacturing furniture.

\section{Maize Cob Particle Board (MCPB) Production Process}

In this section, different materials and methods that were used to achieve the main objective of this research are fully explained. The sequence of this session was started from collection of maize cobs, continued with production of maize cob particle board and ended by testing the final product.

\subsection{Collection and Selection of Suitable Maize Cobs}

In this research, the maize cobs were collected from local maize farmers in Gicumbi district, Northern Province of Rwanda and then transported into the laboratory. Then, eye detection observation was used to check the suitability of maize cobs for removing degraded from desired maize cobs. This is to keep maize cobs with properties shown in Table 1 which are suitable to be used.

Table 1. Compositions of used maize cobs

\begin{tabular}{|c|c|}
\hline Components & $\begin{array}{c}\text { Maize cobs used } \\
\text { [\% of dry matter] [n=1] }\end{array}$ \\
\hline Hemicellulose & 42.8 \\
\hline Cellulose & 35.1 \\
\hline Soluble fraction & 17.3 \\
\hline Lignin & 4.8 \\
\hline Crude protein & 2.5 \\
\hline Starch & 2.1 \\
\hline Crude fat & 0.7 \\
\hline Water soluble & 1.1 \\
\hline Moisture content & 1.7 \\
\hline Ash & 1.8 \\
\hline
\end{tabular}

\subsection{Grinding and Sieving}

After selecting the suitable cobs to be used, they have been crushed or grinded into small particles of different 
sizes by the flour mill machine as shown in Fig. 3 (a). Grinded particles were then sieved through using a sieve shaker to obtain the desired sizes to be used in different layers. Particles that were retained on $6 \mathrm{~mm}$ sieve have been used in making the middle layer of the board whereas those retained on $3 \mathrm{~mm}$ sieve were used in both outer layers [6].

\subsection{Washing, Cooking and Drying}

Referring to the process that was used in the research of [7], the crushed particles were submerged in water for 15 minutes to remove dust and sand particles. As shown in Fig. 3(b), the particles have been cooked for 2-3hrs for the purpose of softening the particles and also achieving a complete disintegration of the material. After cooking, particles have been squeezed by hand to lose some amount of water and they were then exposed to sun for 72 hours during the day at the temperature ranging between $25^{\circ} \mathrm{C}$ and $28^{\circ} \mathrm{C}$.

After these preliminary activities, the thinner particles for both outer layers $(5 \mathrm{~cm}$ thick each) and the thicker particles for the middle layer $(20 \mathrm{~cm}$ thick) with the accuracy of $\pm 1 \mathrm{~cm}$ for each layer were mixed (Fig. 1 (c)). A mixture of $220 \mathrm{~g}$ of finer maize cobs particles, and $60 \mathrm{~g}$ of starch were used to make both face layers, and core layer mixture was $1190 \mathrm{~g}$ of maize cobs particles, $85 \mathrm{~g}$ of starch binder and $5 \mathrm{~g}$ of $3 \mathrm{~cm}$ long sisal fibres mixed in. This was not only done to strengthen the board but also to increase the bonding ability in the core layer [8].

The first face layer was manually casted and pre-compacted or pre-pressed in the prepared $(20 \mathrm{~cm} \times 30 \mathrm{~cm} \times 30 \mathrm{~mm})$ formwork by rolling a bottle at the surface for simple hand compaction (Fig. 1 (d)). Then, a sisal fibres mesh were placed before casting the second layer.

Sisal fibers have been mainly used as the reinforcements. The physical and mechanical properties of used sisal fibers are determined as illustrated in Table 2 and Table 3 [9].

As shown in Fig. 1(e), Sisal fibres were arranged longitudinally and transversally with the spacing of $2 \mathrm{~cm}$ in both directions for increasing its tensile forces resistance and then $30 \mathrm{~g}$ of neoprene glue which is named technically as polychloroprene and chemically composed of carbon and hydrogen atoms was spread at the surface to provide a high bonding strength of a layer to another and sisal fibres.

The next step was to apply the core layer of the thicker particles whereby it was casted and compacted in the same way as the previous layer and the same sisal fibre-mesh was applied as well as neoprene glue. Lastly, the final layer similar to the first one was then casted and compacted with the same procedures as the previous layers.

After having a complete manually 3 layers compacted board, the next step was to compress hard the board in the formwork into the jaws of the bench vice (Fig. 3(f)) by applying approximately $3.806 \mathrm{~N} / \mathrm{mm}^{2}$ and the board was let in the vice jaws for 12 hours to maintain the shape. Two wooden plates were used during compressing with bench vice as they were facing the particle board's two faces in order to distribute the compression forces from the jaws to the particle board and to protect the board from being damaged by jaws of the vice. (Fig. 3 (g)) shows the proposed maize cobs particle board. However, this can be improved by applying different surface finishes as discussed in the next section.

Table 2. The physical and mechanical characteristics of sisal fibres [9]

\begin{tabular}{|c|c|c|c|c|c|c|}
\hline Fibre & $\begin{array}{c}\text { Diameter } \\
(\text { micro-m) }\end{array}$ & $\begin{array}{c}\text { Density } \\
(\mathrm{Kg} / \mathrm{m} 3)\end{array}$ & $\begin{array}{c}\text { Tensile Strength } \\
(\mathrm{MPa})\end{array}$ & $\begin{array}{c}\text { Tenacity } \\
(\mathrm{MPa})\end{array}$ & $\begin{array}{c}\text { Elastic Modulus } \\
(\mathrm{GPa})\end{array}$ & $\begin{array}{c}\text { Elongation at } \\
\text { Break }(\%)\end{array}$ \\
\hline Sisal & $50-200$ & 1450 & $400-700$ & $568-640$ & $09-12$ & $06-14$ \\
\hline
\end{tabular}

Table 3. Chemical composition of sisal fibres [8]

\begin{tabular}{|c|c|}
\hline Cellulose & $65 \%$ \\
\hline Hemicelluloses & $12 \%$ \\
\hline Lignin & $9.9 \%$ \\
\hline Waxes & $2 \%$ \\
\hline Total & $100 \%$ \\
\hline
\end{tabular}




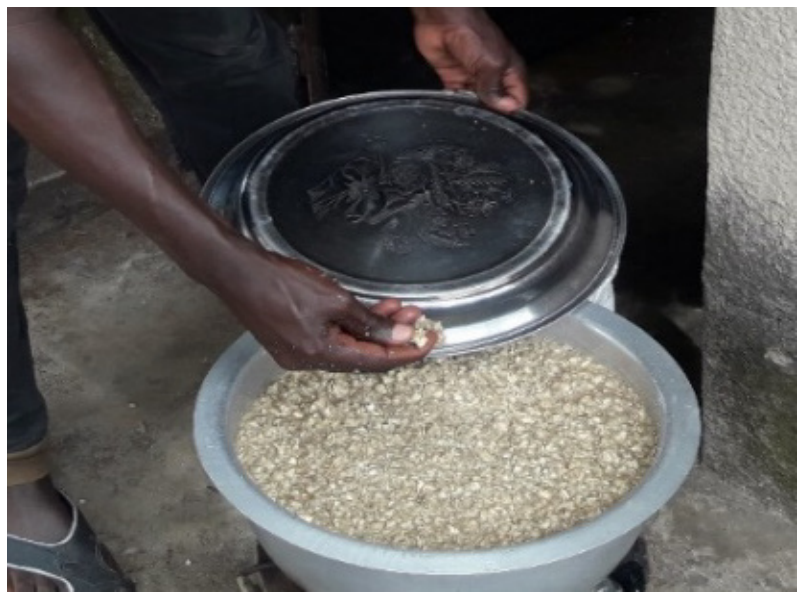

Figure 1 (a). Grinding

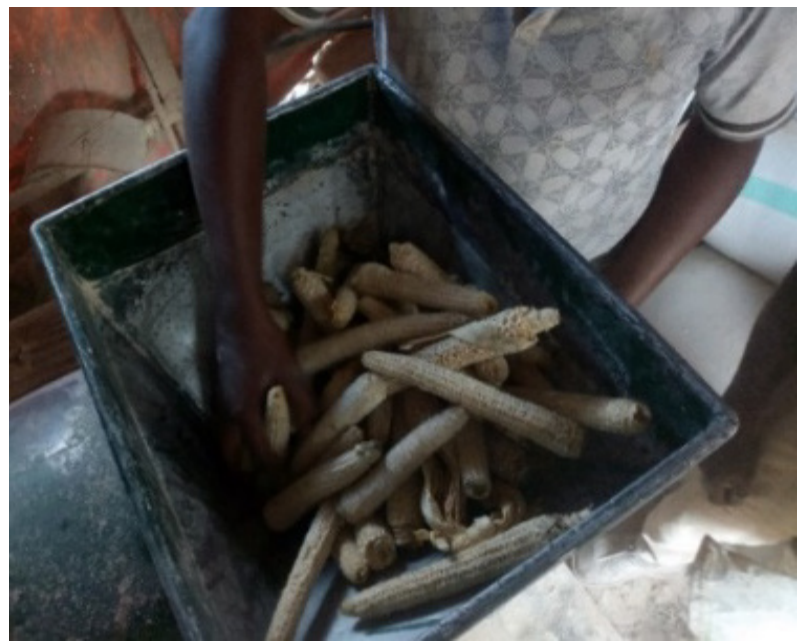

Figure 1 (b). Cooking

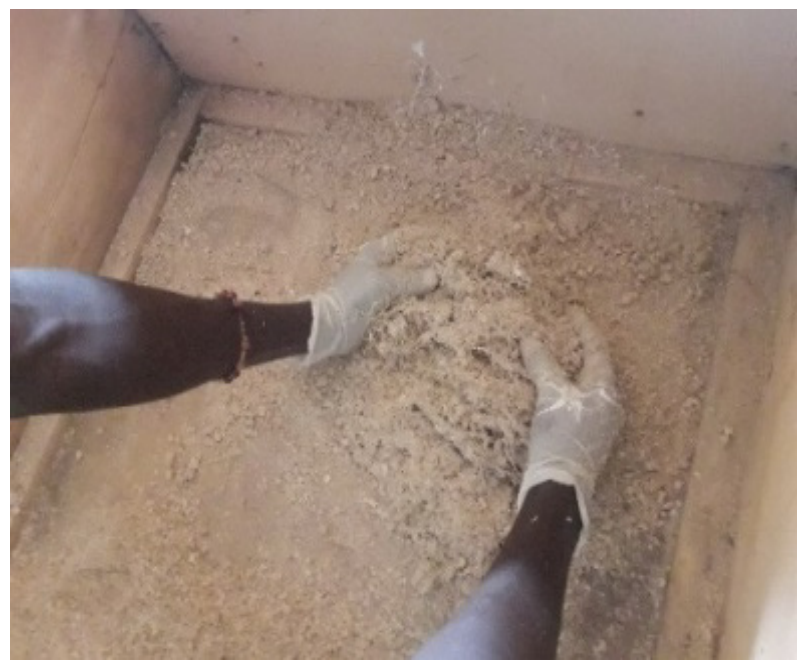

Figure 1 (c). Mixing

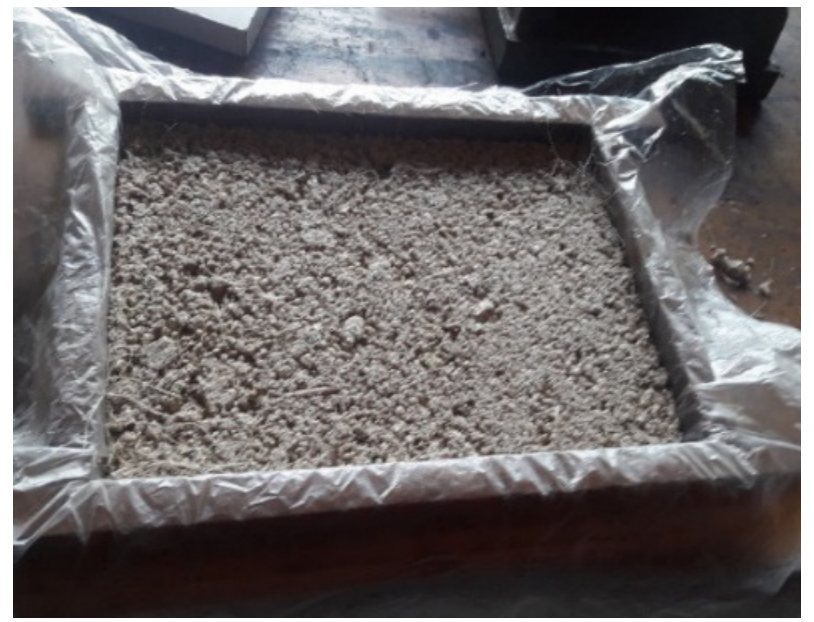

Figure 1 (d). Matt forming

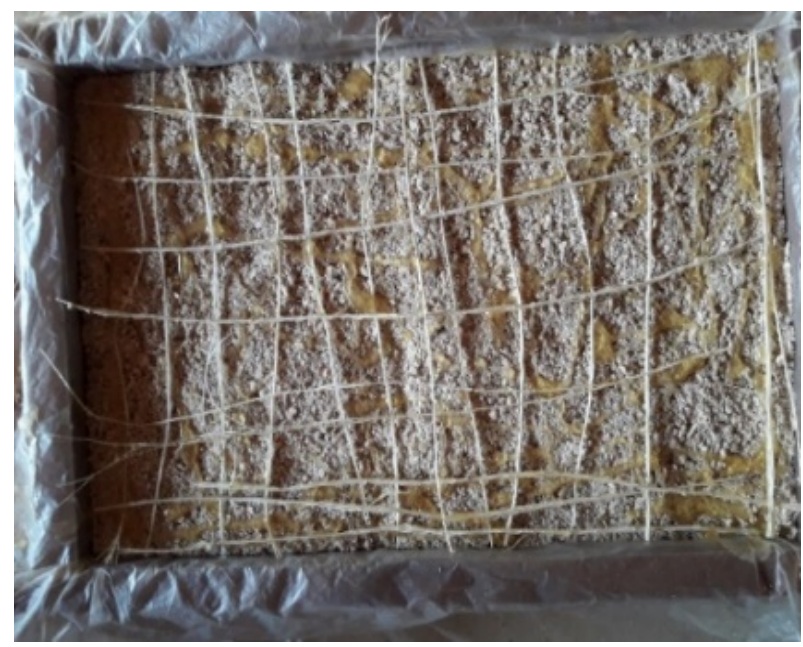

Figure 1 (e). Sisal fiber mesh

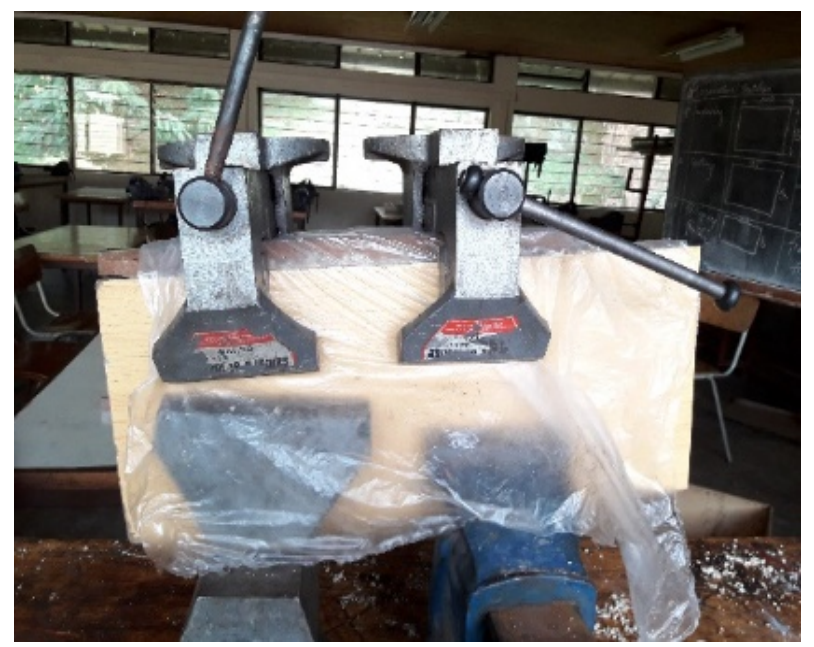

Figure 1 (f). Compressing 


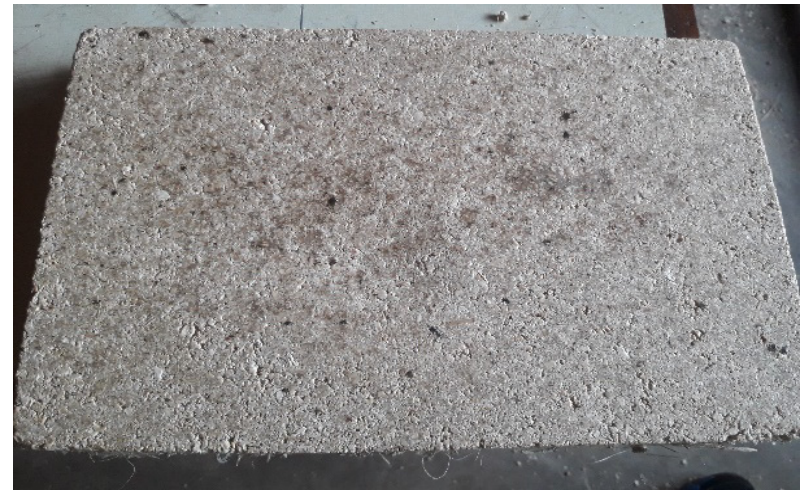

Figure 1 (g). $\mathrm{MCPB}$

\subsection{Board Finishes}

Since this 3 layer MCPB was found to have low resistance on water penetration it was found that it has to be protected and many ways are possible as other Particle boards where they can be finished in different ways such as laminating them, painting them, varnishing them and applying a veneer cover on them as shown in Fig. 2.

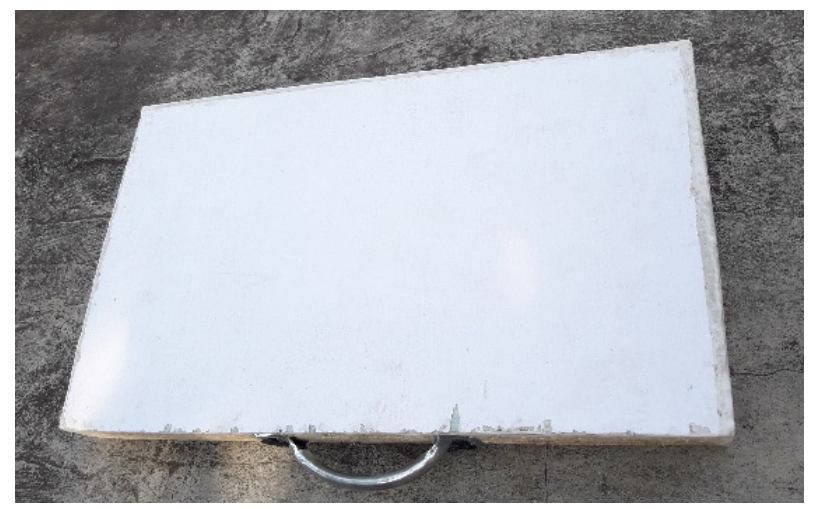

Figure 2. Finished board

\section{Tests and Results}

In this research, tests were conducted to check the efficiency (physical and mechanical properties) of the produced board (MCPB). In this section, the physical characteristics analyzed are the density, moisture content, water absorption test and one mechanical characteristic which is screw holding and this session is briefly explaining all the results, discussions and comments of what have been found during production of maize cob particle board and the results of conducted tests.

\subsection{Density Test}

The density of any test piece is measured by reference to its weight and dimensions. In accordance with [10], the mean density of a particle board, when tested, shall vary between 500 and $900 \mathrm{~kg} / \mathrm{m}^{3}$. Thus, in this research a specimen (MCPB) of $30 \mathrm{~cm}$ long, $20 \mathrm{~cm}$ wide and $3 \mathrm{~cm}$ thick was made and its density was calculated using the following procedure.

\section{Procedures}

The above-mentioned specimen was weighed on the balance and the mass was recorded as $\mathrm{M}=1.35 \mathrm{~kg}$. And its volume was simply calculated by multiplying its dimensions i.e, $V=0.00018 \mathrm{~m}^{3}$. As mentioned earlier, the density of any specimen is measured by the ratio to its mass $\mathbf{M}$ and volume $\mathbf{V}$ and this can be expressed using a simple equation below:

$$
D=\mathrm{M} / \mathrm{V}
$$

Replacing the mass and volume of the specimen obtained before into the above equation $(0.1)$, the density of the three-layer maize cob particle board (MCPB) was obtained as $D=750 \mathrm{~kg} / \mathrm{m}^{3}$. Thus, proving that the proposed MCPB is accepted within range as per[10]. It is noted that the changes in the moisture content in the board will affect its density. This may be mainly affected by a prolonged storage in either too dry or too humid conditions.

\subsection{Moisture Content}

In this section, two specimens (Specimen 1 and Specimen 2) were manufactured and the moisture contents in the two specimens were calculated and compared referring to the Indian standard IS 2380 [11] using the following equation:

$$
\text { Moisture content }=\frac{M_{1}-M_{2}}{M_{2}} \times 100
$$

With $M_{1}$ and $M_{2}$ being the Mass of the specimens before and after drying the specimen in an oven for a period of time, respectively.

Specimen 1 represents a MCPB produced without sisal fibers, whereas, specimen 2 represents a MCPB reinforced with sisal fibers between layers. The dimension (length $\mathrm{x}$ width $\mathrm{x}$ thickness) of specimen 1 and 2 are $30 \mathrm{~cm}$ x $20 \mathrm{~cm}$ x $20 \mathrm{~mm}$ thick and $25 \mathrm{~cm} \times 15 \mathrm{~cm} \times 15 \mathrm{~mm}$, respectively.

In order to measure the moisture content within the two specimens, the initial mass $M_{1}$ prior oven-drying of each of the two specimens were recorded as $\mathrm{M} 1=1350 \mathrm{~g}$ for specimen 1 and $\mathrm{M}_{1}=1278 \mathrm{~g}$ for specimen 2 . Then, the two were oven dried at a temperature of $103 \pm 2$ Celsius degrees till the mass is constant to \pm 0.2 percent between two successive weightings. The mass $\mathrm{M}_{2}$ after oven-drying of each of the specimen were $\mathrm{M}_{2}=1323 \mathrm{~g}$ for specimen 1 and $\mathrm{M}_{2}=1253 \mathrm{~g}$ for specimen 2 , as shown in Fig. 3. Then by using equation (1.2), the moisture content wet basis in specimen 1 is found to be $2.041 \%$ and $1.995 \%$ for specimen 2 . The MCPB reinforced with sisal fibers has less moisture content than the one without sisal fibers (Fig. 3).

The moisture content of maize cob particle board produced during the research is preferable because the percentage is below $5 \%$ that is considered as the minimum required. 


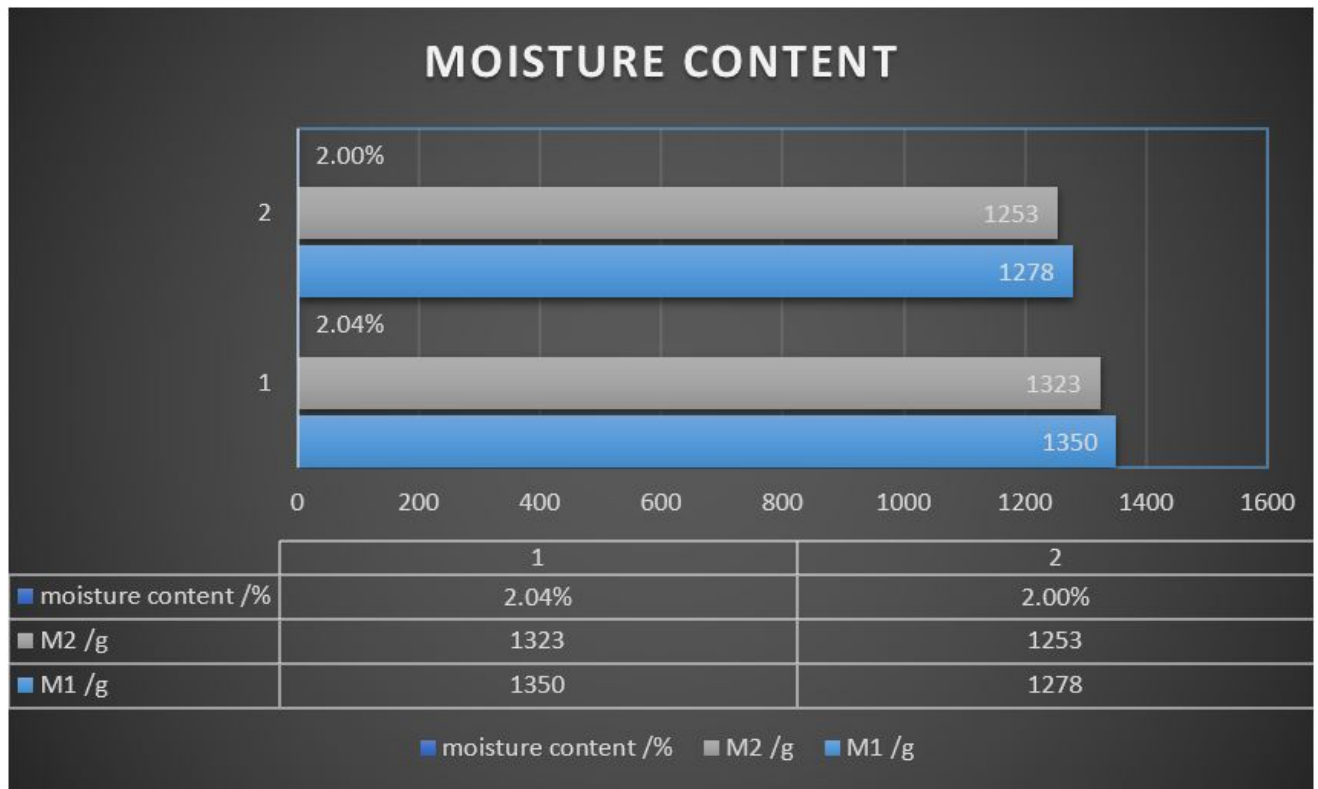

Figure 3. Moisture content chart

\subsection{Water Absorption Test}

The water absorption test was performed on board specimens $(15 \mathrm{~cm}$ wide $\times 20 \mathrm{~cm}$ long $\times 3 \mathrm{~cm}$ thick $)$ for determining the amount of water absorbed by the board under specified conditions. Here, specimen 1 is the specimen that is reinforced with sisal fibres in it, whereas specimen 2 does not contain sisal fibres.

During this test, the two specimens were weighed before immersion in water to an accuracy of $0.2 \%$. Then, they were immersed in water and weighed progressively after 2 hours and 24 hours. $M_{1}$ represents the mass of the specimen before submersion in water, $\mathrm{M}_{2}$ is the mass of the specimen after being submersed in water for 2 hours and $\mathrm{M}_{3}$ is the mass of the specimen weighed after 24 hours in water.

For specimen 1,

$\mathrm{M}_{1}=579.6 \mathrm{~g}, \quad \mathrm{M}_{2}=687.3 \mathrm{~g}, \quad \mathrm{M}_{3}=912.7 \mathrm{~g}$.

For specimen 2,

$$
\mathrm{M}_{1}=395.2 \mathrm{~g}, \quad \mathrm{M}_{2}=772.7 \mathrm{~g} . \quad \mathrm{M}_{3}=
$$

here, Specimen 2 failed

$\mathrm{M}_{1}$ : Mass of the specimen before being immersed in water

$\mathrm{M}_{2}$ : Mass of specimen after 2 hours immersion in water

$\mathrm{M}_{3}$ : Mass of specimen after 24 hours immersion in water

\section{Calculations}

\section{Specimen 1}

Water absorption after 2 hours $=\frac{687.3 \mathrm{~g}-579.6 \mathrm{~g}}{579.6 \mathrm{~g}} * 100=$ $18.59 \%$

Water absorption after 24 hours $=\frac{912.7 g-579.6 \mathrm{~g}}{579.6 \mathrm{~g}} *$

$$
100=57.47 \%
$$

Specimen 2

Water absorption after 2 hours $=\frac{772.7-395.2 \mathrm{~g}}{395.2 \mathrm{~g}} * 100=$

$$
75.52 \%
$$

Fig.4 shows the specimen 2 which failed after submerging it into water after 5 hours. Whereby, its particles separated completely.

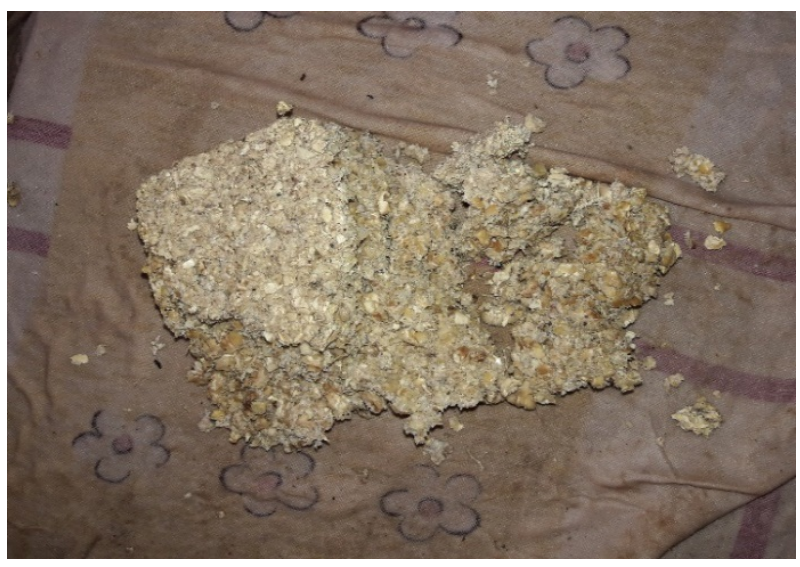

Figure 4. Failed Specimen 


\section{WATER ABSORPTION}

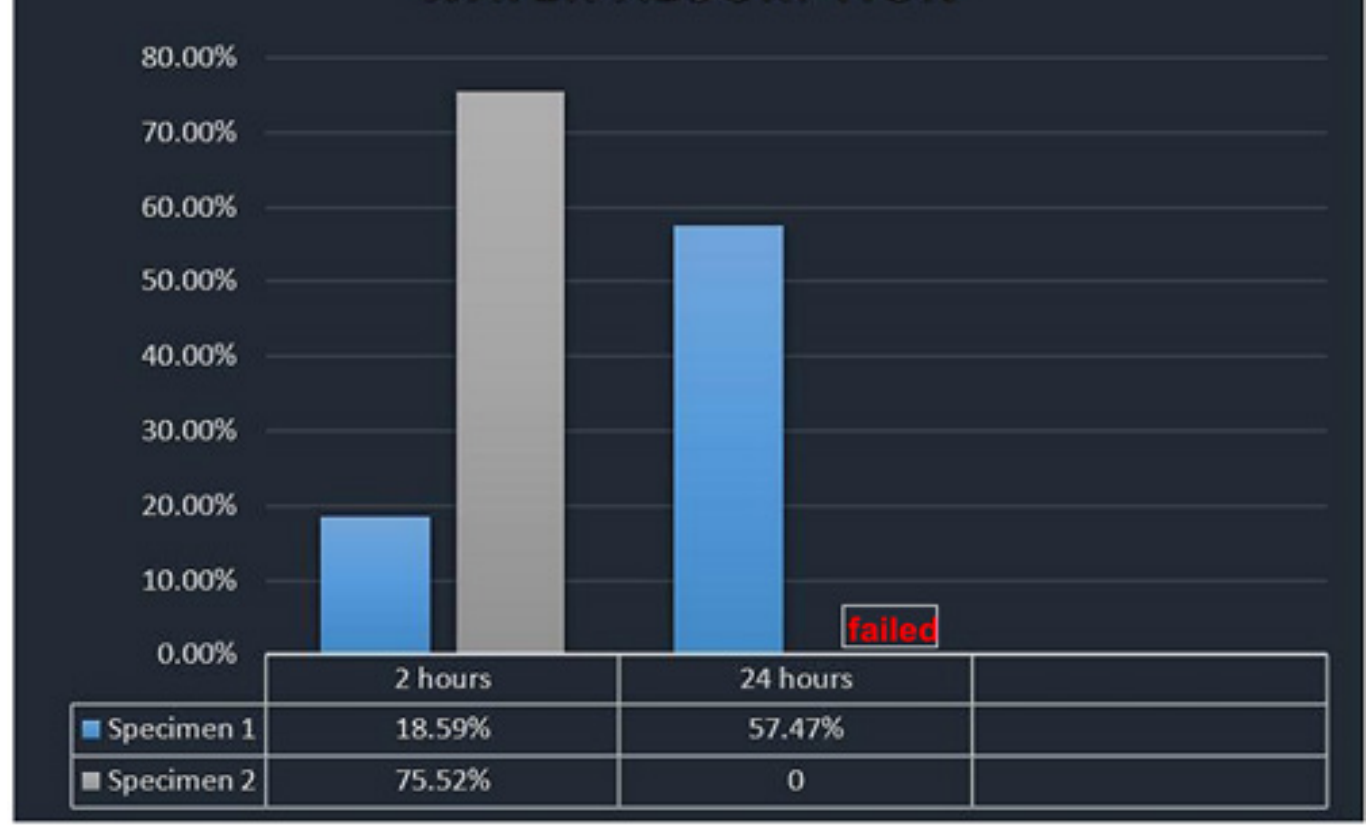

Figure 5. Water absorption chart

As shown in (Fig. 5), the results of water absorption test on specimen 1 greatly meet the Indian standard [11]. Since after 2 hours $(18.59 \%)$ and 24 hours $(57.47 \%)$ water absorption has gone below $40 \%$ and $80 \%$ respectively as maximum allowable water absorption percentage, whereas the specimen 2 which is not reinforced by sisal fibres was not suitable for Indian standard since it does not fulfil the standard.

\subsection{Screw Holding Test}

The test was performed on specimen of $150 \mathrm{~mm}$ length, $75 \mathrm{~mm}$ wide respectively, and $30 \mathrm{~mm}$ thick for determining screw-holding strengths. The results of this test have shown that the board can withstand screws as well as accessories either on the faces or sides [11] as shown in Fig 6.

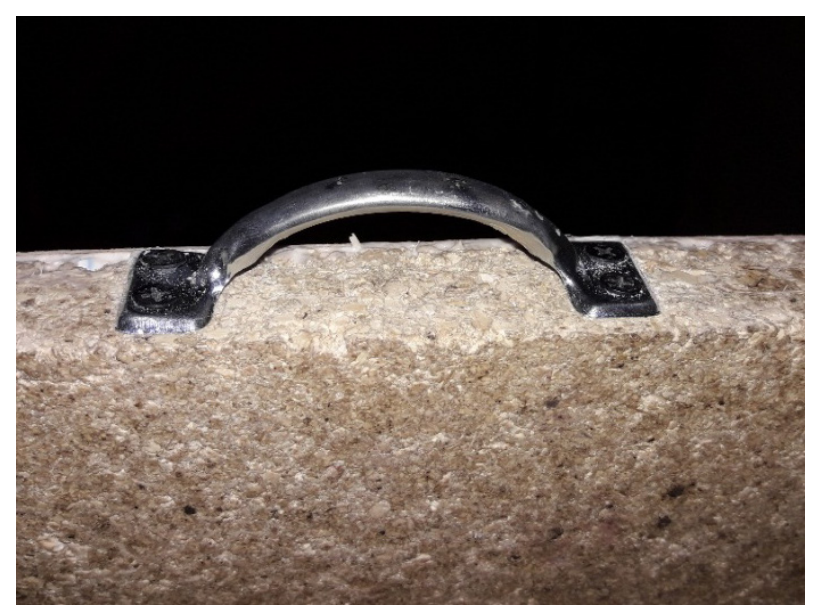

Figure 6. Screw holding a knob

\section{Conclusions}

The aim of this research was to propose a particle board made from crushed maize cobs that can be used to manufacture different equipment including furniture. Maize cobs were primarily collected and the suitable was selected, grinded, sieved, mixed with glue and sisal fibres, compressed and later being tested to check their effectiveness. According to the result of this research, the following conclusions were drawn:

1. This research has found that in manufacturing this board, sisal fibers can always be used to increase not only the bonding strength but also the tensile strength.

2. Since the water absorption resistance of this particle is very low, it is advised to always apply veneer cover for its protection against water penetration and humidity.

3. All tests evaluated satisfy the minimum standard for wood particle board.

4. The board properties were generally dependent on adhesive concentration level. Sample boards with higher resin content were inferior in board properties than those with lower resin content level.

5. This maize cob particle board appears to be a good material that can be competitive and productive in the market.

6. Future researches can be drawn from this research in order to increase the strength and effectiveness of this $\mathrm{MCPB}$ proposed in this research. 


\section{REFERENCES}

[1] H. Jamal, Civil Construction Materials, 22 October 2017. [Online]. Available: https://www.aboutcivil.org/engineerin g-materials.html.

[2] J. Petterson, Wood, 26 June 2015. [Online]. Available: https://www.the-warren.org/GCSERevision/resistantmateri als/wood.html.

[3] R. Fishkin, Particle board advantages and disadvantages, 12 February 2012. [Online]. Available:blog.positiveindians.in /particle-board/particle-board-advantages-disadvantages.ht ml.

[4] GharPedia, 7 Uses of Particle Board in Building Industry, 2019. [Online]. Available: https://gharpedia.com/uses-of-p article-board/. [Accessed 6 September 2019].

[5] E. Ntirenganya, Experts seek ways to increase Africa's maize production, 10 february 2017. [Online]. Available: https://www.newtimes.co.rw/section/read/207870.

[6] A. E. F. L. J. H. Chittenden, Particle Boards from Pinus Caribaea from Fiji, L29, Tropical Products Institute, p. 11, 1970.

[7] I. Khalilullahi, The Suitability Of Maize Cobs For The Production of Particle Board, Ahmadu Bello University, Zarla/ NIGERIA, 1989.

[8] M. I. Kiron, textilelearner.blogspot.com, 2013. [Online]. Available:https://textilelearner.blogspot.com/2013/01/sisal -fiber-properties-of-sisal-fiber.html. [Accessed 286 2019].
[9] M. Roberts, wild fibres, wild fibres, 3112017 . [Online]. Available: http://www.wildfibres.co.uk/html/sisal.html. [Accessed 286 2019].

[10] H. Paul, Standard Test Methods for Evaluating Properties of Wood-base Fiber and Particle Panel Material, 1st ed., West Conshohocken: ASTM International, 2003.

[11] J. Nehru, Physical and mechanical properties of various types fo particle board, in Particle Boards Of Wood And Other, Bhartṛhari and Nìtiśatakam, Eds., New Delhi, Bureau Of Indian Standards, 2005, p. 18.

[12] Reade International Corp, Binder Materials, Organic, 2018. [Online]. Available: https://www.reade.com/products/bind er-materials-organic. [Accessed 2105 2019].

[13] C. Flora, Wood advantages, 07 October 2008. [Online]. Available: https://www.feim.org/en/wood-advantages.

[14] Oxford Dictionary, Chicago, 2010.

[15] T. Anderson, Advantages and Disadvantages of Particle Board, Gharpedia, 25 September 2018. [Online]. Available: https:/gharpedia.com. [Accessed 20 January 2019].

[16] P. Luo, Production of particle boards using rice straw pre treated with liquid hot water, Applied Mechanics and Materials, 200 (2012) 331-334.

[17] k. Lambert, www.best cob.com, 2019. [Online]. Available: https:/www.bestcob.com/about-best-cob/why-corncob/. [Accessed 65 2019].

[18] snellnaninkatu, wood products.fi, 2013. [Online]. Available: https://www.woodproducts.fi/content/particle-board. [Accessed 286 2019]. 